\title{
肝囊胞性腫瘍一CMS の疾患概念からみたー
}

\section{草野 満夫}

\section{はじめに}

肝壤胞腺癌は多彩な病態を呈するが，その histogenesis が依然と不明であることから，古くより症例 報告を中心に, 成因, 病態へのアプローチが試みられ てきた。しかし，本邦でも肝癌16539例中わずか32例 $(0.19 \%)^{1)}$ と希な腫瘍であり, その発生様式, 臨床病態, 診断法, さらには治療後の再発形式, 予後などについ て, 未だ十分に明らかにされているとは言い難く, ま た本疾患の定義, 名称にも一定の見解が得られていな い. 近年, 本疾患に関してのいくつかの知見が報告さ れ, 新たな視点から本疾患を再度, close-up する必要 性が出てきた。今回これまでの報告を中心に, 本疾患 の病態を reviewしたい.

\section{I 、呆胞腺癌における新たな視点}

6 例の自験例があるが(表 1)（襄胞形成性末梢胆管細 胞癌 1 (例を含む) ${ }^{2 \sim 4)}, 2$ 例は腺腫内出血, 1 例 ${ }^{4}$ は縦隔転 移を有しつつ, 初発から 5 年間, 健在な症例もあり, 症例ごとに多彩な病態を呈することも，その病態を十 分に把握しえない要因となっている.1991年に川原田, 水本ら ${ }^{5,6}$ により，詳細な症例の検討とそれに基づいた 分類が提唱され，これまでの報告もそれに準じて行わ れている. その視点は de novo type か, 発癌母地が腺 腫あるいは単純褧胞なのかの鑑別の必要性から, 㖶胞 壁の良・悪病変移行帯の組織形態に重点が置かれてき

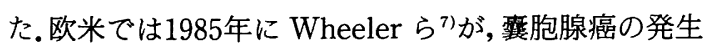
母地である襄胞腺腫の特徵的な間葉性間質 (cystadenoma with mesenchymal stroma : CMS) の存在の重 要性を指摘したが, しかし本邦では症例数が少ないこ ともあり注目されないままであった。一方, “ovarianlike" stroma が女性の腺腫に高頻度に認められ, かつ 腺癌であってもきわめて予後が良好であるとの報告8)や， また, 1997年には Terada ら ${ }^{9} は$ 間質内に内分泌系細胞 の存在と, peribiliary gland との関連性を報告し, そ の知見に基づいた本症の発生部位, 機序についての新 しい見解を示した.

この間,一方では膵における mucin-producing tumor

昭和大学第 2 外科
との組織発生における類似性も論じられるようになっ た. 本疾患の病態について肝, 膵の衰胞性疾患に共通 する成因も含め, 概説したい.

\section{II. 疾患概念の変遷}

1958年, Edmondson ${ }^{10}$ は 49 歳, 白人女性の腺腫 (bile duct adenoma)の症例を報告した．腺腫壁は円柱状上 皮で覆われ, 間質は平滑筋原性の性質を有する細胞成 分に富んでいたとし, 胆管腺腫の病理学的特徵を明ら かにした. 1965年には Tompson ら ${ }^{11)}$ Intrahepatic cystadenoma of bile duct origin with malignant alteration として, 㐮胞腺腫からの腺癌の発生例を報告 し, 㖶胞腺癌の多くは良性の腺腫から発癌することを 知らしめた。一方, 単純性肝襄胞の癌化例については 1943年のWillis の報告 ${ }^{12)}$ 以来, 本邦でも小坂ら ${ }^{13)} に よ$ って初めて報告され, 䧶胞腺癌の発癌形式の一つとし て検討されてきた．このような背景を踏まえ，1991年 に川原田・水本らは自験例 5 例の検討を基に新たな分 類を提唱した ${ }^{5)}$. 肝の䧶胞形成性悪性腫瘍を広義的にま ず以下の 3 群に分類した. Group A：賈胞性腺癌 (cystic adenocarcinoma), Group B : bile duct carcinoma with intrahepatic bile duct dilatation:末梢 胆管が粘液産生性の腫晹により閉塞され, 䨢状に拡張 した腺腫様腫瘍 (肝内胆管癌), Group C：degeneration cyst in malignant liver tumor : 原発, 転移性肝 癌がその発育過程で壊死を惹起し, 品腫様形態を呈す る腫瘍.さらに襄胞性腺癌 (cystic adenocarcinoma) と して Aを Type I (cystadenocarcinoma)：いわゆる de novo type の腺癌で, 襄胞壁全体が癌で, 粘液を産 生し, 小䧶胞状を呈するもの, Type II (cystadenocarcinoma with cystadenoma）: 粪胞腺腫の一部が癌化, 乳頭様に増殖したもので, これには単房, 多房性の両 者が存在する, Type III (carcinoma in a simple cyst of the liver)：単純性肝襄胞の癌化したもの, とに分 類した. 成因から考えると非常に理解しやすい分類と なっており, それ以降の症例ではこれに基づいて報告 がされるようになった。しかし，川原田自身指摘して いるが, 臨床上, 多彩な病態を示すこと, 必ずしも発 生母地が同定できないことなどから, 露胞腺癌を胆管 
表 1 肝囊胞性腫瘍

\begin{tabular}{|c|c|c|c|c|c|c|c|c|c|c|c|}
\hline No & & 年齢・性 & 年代 & 主訴 & 肝腫大 & US,CT 所見 & Angio & 治療法 & Size $(\mathrm{cm})$ & 分類5) & 臨床経過 \\
\hline 1 & YM & $79 \mathrm{~F}$ & 1984 & 腹部腫瘤 & + & cystic+隆起病変 & hypo & 左葉切除 & 10 & Type II & 腺腫 $\rightarrow$ 腺癌 \\
\hline 2 & IH & $50 \mathrm{M}$ & 1985 & 腹部腫瘤 & + & cystic+隆起病変 & - & 左葉切除 & 11 & Type II ? & 3 年 1 力月死亡 \\
\hline 3 & $\mathrm{OK}$ & $74 \mathrm{M}$ & 1988 & 腹部腫瘤 & + & cystic+隆起病変 & hyper & 拡大左葉切 & 15 & Type II & 左胆管閉塞 \\
\hline 4 & $\mathrm{KT}$ & $56 \mathrm{M}$ & 1994 & 腹部腫瘤 & + & cystic+隔壁 & hyper & 左葉切除 & 18 & Type II ? & postop 他病死 \\
\hline 5 & $\mathrm{NT}$ & $49 \mathrm{~F}$ & 1993 & 腹痛 & - & 肥厚した襄胞壁 & 出血 & TAE & 25 & Type II & 5 年生存中 \\
\hline 6 & ST & $61 \mathrm{~F}$ & 1984 & 腹痛 & - & 拡張胆管 & hypo & 左葉切除 & 2.8 & Group B & 胆管細胞癌 \\
\hline
\end{tabular}

(自験例)

と連続性をもたない“褒胞形成性の肝原発の腺癌”と し, 一括して検討しているのもある ${ }^{14)}$.

\section{III. 臨床病態}

\section{1. 患者背景}

1）性差：腺腫に“ovarian-like” stroma の存在が示 唆されることから, 発生に性差があることが窺われる. 34 例 (腺腫：27, 腺癌：7 )のうち,女性は32例 (94\%) ${ }^{15)}$ で, 腺腫52例中50例は女性 ${ }^{8)}, 21$ 例の本邦症例では女性 は15例 $(71.4 \%)$ など ${ }^{16)}$, 腺腫は女性に圧倒的優位な病変 であることに注目したい.一方腺癌であるが, 自験例, 肝癌追跡報告でも ${ }^{1)}$, 一定の傾向はなかったが, 腺癌 18 例では $8: 10^{8)}$, 本邦の腺癌18例においても $6: 12$ と $^{16)}$, やはり女性に多い傾向であった。さらに興味あること は間葉性間質 (mesencymal stroma, MS) を有する腺 腫 (cystadenoma with mesenchymal stroma, CMS) は, 17 例 ( 4 例の癌化症例も含む) 全例が女性で7), 同様

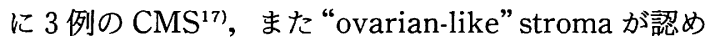
られた44例はすべて女性であった7)との報告は, この疾 患の成因とも絡んで興味ある事実である，この点に関 しては後でもう一度触れる。

2）発生年齢：本症が先天性の発生, 腺腫からの発癌 などの成因が考えられており，その年齢分布も興味深 い. 腺腫では 2-87歳 (平均発生年齢：45歳), 腺癌では 24-90歳(平均59歳) で8), CMS では平均41.7歳, 4 例の 悪性変化を来したCMS では58.5歳と後者が高年紫で7), 自験例では49-79歳で平均61.6歳,腺癌では腺腫49.1歳 に比べ57.1歳 ${ }^{16)}, 24-67$ 歳(平均55歳) ${ }^{18)}$ であったなど, 10歳以上，腺癌の初発年齢が高くなっている。一方, $\mathrm{MS}$ を有しない腺腫の発生平均年代は53.4年と CSM よ り高く,この点からも両者の病態の相違が見られる7).

\section{2. 画像診断}

症例 $1^{2)}$ は79歳, 女性, 肝哓胞と診断. 高齢で全身状 態が不良のため, 開空術のみ行った。病理診断は肝顀 胞腺腫であった. 1 年 8 カ月後に CT 等で癌化再発, 賈 胞腺癌と診断, 再開腹した. 凹凸不整な左葉の腫瘤と,
一塊となった小・大網と腹膜, 腸間膜への播種性転移 が見られ，壤胞腺腫の癌化であった，入院時，画像で 衰胞腺腫が強く疑われていれば, 初回より手術に踏み 切ったかもしれない.ここで画像上，両者が鑑別可能 か否かが問題となる ${ }^{15 \sim 26)}$.

1) US, CT：露胞壁の部分的肥厚, 乳頭状に突出す る, 充実性のエコー(mural nodule), 厚さが不均一な 隔壁などが特徴的な所見で, 多くは多房性のため, 部 分的に蜂巣状に見えることがある.CT も巨大な円形の 低吸収領域として同定され，隔壁, mural nodule はや や density が高い領域として認められる. Choi ら ${ }^{24)}$ は 肝包虫症の囊胞壁にしばしば羿められるような石灰化 像を囊胞腺腫, 䧶胞腺癌 1 例ずつに確認, 直居ら ${ }^{27)}$ も同 様の所見を捉えている。

2） MRI：縗胞内は粘液, あるいは出血による貯溜し た血液等が存在し,これらの副病変の描出にも MRIの 診断的価值は高い. 自験例 1 は亯胞腺癌の貯溜液が mucin であったことにより, T2 強調像で不均一な高〜低 信号の混在像が見られ，悪性を疑う有力な根拠となっ

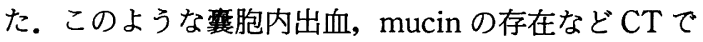
は検出しづらいこともあるが, MRI では T1, 2 ともに 高信号を示すため, 有力な情報を提供してくれる26).

3）肝動脈造影：多くは襄胞に一致して肝内血管の圧 排, 伸展が見られる.腫瘍性病変部に軽度の腫瘍血管 の増生と濃染像を見ることがあるが15), 肝包虫症のよう な血管の途絶, encasement は見られない. 自験例 $5 て ゙$ は襄胞内出血を血管造影で確認しえた。

これらの画像診断は肝䧶胞か䧶胞腺癌かを鑑別する にはある程度有用であるが, 残念ながら, 霟胞腺癌が 肝䧶胞あるいは䧶胞腺腫から発癌したかの鑑別は必ず しも容易ではない. しかし, Buetow ら ${ }^{15)}$ は34例の桽胞 腺腫，腺癌を詳細に検討し，両者を明確に鑑別するこ とは困難ではあるとしながらも, 隔壁と結節病変, 䧶 胞内出血巣の存在, 襄胞壁, 隔壁の石灰化は亯胞腺癌 を，隔壁のみ，mucin の存在は哓胞腺腫を強く疑わし 
める所見としている.また,CMS, “ovarian-like”stroma の存在が予後規定因子となりうる可能性があることか ら，その存在を画像的に捉えられるか否かが今後の課 題でもあるとしている。

4) 腫瘍マーカー, 細胞診 : 血清中の腫瘍マーカーで あるが自験例では AFP は正常範囲, CEA, CA19-9 の 高值例が 1 例ずつ見られた. AFP, CEA の陽性率はそ れぞれ，1/18(6\%)，5/14(36\%) と AFP の陽性率は低 い $^{28)}$. CEA については $20.27 \mathrm{ng} / \mathrm{m} l$ と高值を示し, 組 織染色でも CEA 強陽性であった腺癌症例 ${ }^{29}$, CEA： $7.5 \mathrm{ng} / \mathrm{m} l, \mathrm{CA} 19-9: 154 \times 10^{4} \mathrm{U} / \mathrm{m} l, \operatorname{SPan}-1: 860$ $\mathrm{U} / \mathrm{m} l$ と異常高值を呈した腺腫症例などがあるが30),一 定の傾向はないようである．輁胞夜中の腫瘍マーカー について西ら ${ }^{29)}$, 北尾ら ${ }^{31}$ によると, CEA は襄胞に比 べ襄胞腺腫, 腺癌に高く, CA19-9 は単純性壤胞でも高 值を示す例が少なくなく, 腺腫, 腺癌はさらに高值を 示すとしている.したがって, CEA, CA19-9 両者が高 ければ, 肝囊胞よりは腺腫, あるいは腺癌を疑うべき としている ${ }^{31}$. 竹内ら ${ }^{32)}$ は肝襄胞性疾患49例について, 豪胞内容液, 血清の CA19-9, CEA, 内容液の細胞診断 について検討したが, 腺腫, 腺癌の鑑別には役立たな かったと結論づけている.このように確定診断が困難 なことから, US 下生検を行った報告 ${ }^{33 \sim 37) も あ る . ~ し か ~}$ し, 肝䧶胞の診断はそれ程困難ではなく，また，たと 充襄胞腺腫であってもその性格から，外科手術が原則 であることから，穿刺による播種性転移の可能性もあ ること ${ }^{36,37)}$ ，また穿刺細胞診で negative であっても， 悪性を否定しきれないことから，無意味な穿刺は控え るべきであろう. 本疾患を疑った場合, 組織化学的検 索は重要である.AFP の上昇した症例を組織化学的に も確認した症例 ${ }^{38)}$, また 3 例の腫瘍性壤胞について, CEA が腺腫および腺癌の良性部分の腺細胞の表面のみが染 色されたのに対して, 腺癌は細胞質までび慢性に染色 された ${ }^{39}$, 同様に肝襄胞 $1 / 6$, 腺腫 $2 / 5$, 腺癌 $12 / 13 k$ CEA 染色が陽性であった ${ }^{32)}$ などの報告がある.このように組 織化学的検索は良性, 悪性の鑑別, 予後判定の一指標 となりえ,ルーチンに行うべきと考える.

\section{3. 臨床像}

1）肝哓胞腺腫：本邦では少なく1994年まで21例16) で，その後1997年まで数例の報告 ${ }^{40 \sim 44)}$ があるのみであ る.

1-15年の経過観察した50例の腺腫 (43例が外科切除手 術を受け, 7 例が生検, 開空術などの治療が行われて (るが)についてみると ${ }^{8)}$, 手術例 1 例に腺腫の再発が,
開空術など姑息手術を行った 6 例のうち 2 例が病変を 持ちながら生存しており，概ね良好な経過をたどった としている.さらに経過観察中にこれら腺腫のうちで “malignant degeneration”を来した症例はなかった ものの, 腺癌の非癌部には腺腫の上皮が存在したとし, 腺腫からの発癌の可能性も指摘している. 本邦では 7 年間経過観察され,切除された腺腫 ${ }^{42)}$, 寺島らによる切 除後の経過良好例 ${ }^{43)}$ と, 集計した 8 例の腺腫は 10 力月 -2 年 6 力月全例生存していたとの報告がある. 6 年間 に 3 回の再発を繰り返した症例45)もあるが, 腺腫は比較 的緩徐な発育経過をたどるものが多い.

2) 腺腫から腺癌へ：自験例 $1,3,5$ では腺腫から腺 癌を強く疑われた症例であり, 症例 3 では, 噻胞壁は 大部分が乳頭様増殖を伴った多層性の円柱上皮で内張 りされており, 核配列の乱れ, 細胞分裂增及び構造異 型が認められ, 乳頭状腺癌であった。同時に異型性の そしい単層の円柱上皮も認められた。このように良性 の晓胞腺腫上皮と腺癌の像が比較的境界明瞭に混在し ていたことより, 腺腫からの癌化と判定された. 腺癌 18 病変の検討 ${ }^{8)}$ では $3.0 \mathrm{~cm}$ が最も小さい腫瘍であった とし, 本邦では径 $2 \mathrm{~cm}$ の単純性肝衰胞からの腺癌 ${ }^{39}$ が 最も小さいようである.本邦でも1996年までに18例16), その後現在まで10数例の報告がある. Ishak ${ }^{46)} ら は 6$ 例,

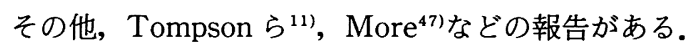
多くは外科的に切除され, その予後は比較的良好との 報告が多い. 症例 5 は腫瘍内出血で, 手術を拒否され たため, 緊急 TAE を施行した症例で, 初回入院より 4 年 6 力月経過した現在, 縦隔に転移しているものの, 通常に生活している.初回入院時の CT では S8 を中心 $に 15 \mathrm{~cm}$ 径の内部に high density area を伴う low density mass を認めた。造影 CT, 動脈造影で造影剂の漏 出が見られ出血判断, TAEを施行した. 施行後患者の 強い希望で退院となったが, 徐々に腫瘍は増大し, 2 年 9 カ月には喀血を来し, 縦隔転移が確認された。こ のように腫瘍の発育は比較的緩徐ではあるが，同時に 転移を来す症例, 短期間の進展 ${ }^{48)}$, 翼胞内出血 ${ }^{3,4}$, 腹 膜播種 ${ }^{2,49)}$, 胆管への浸潤50)などの報告もあり, 腺癌は 多彩な発育・進展様式を呈する.

3）单純性㖶胞よりの癌化：Type IIIに相当する。単 純性肝蛮胞の癌化例は極めて希である. Willis の報告 ${ }^{12)}$ 以来, 先天性襄胞からの癌化 ${ }^{51,52)}$, 壤胞からの扁平上皮 癌淿などが報告されてきた.しかし Azizah ら ${ }^{54)}$ は 1 例 の襄胞腺癌と, 襄胞が発育につれて胆管細胞癌の発生 を見た 2 症例を報告し, 両者は根本的に異なる疾患で 
あると指摘している.本邦でも症例報告が相次ぎ55 57), 川原田ら ${ }^{58)}$, 松下ら ${ }^{59}$ による集計で，これまで30例以上 の症例がある．肝襄胞の経過観察中に腺癌の発生を見 たものも 4 例報告され，その観察期間は最短 2 年, 最 長10年であった ${ }^{60)}$. 肝䧶胞からの癌化は実験的にも確認 され ${ }^{61)}$, Aflatoxin を投与することにより,ラットに多 発性の襄胞とその一部が癌化した言胞腺癌が見られる. Ameriks ら ${ }^{62)}$ は21歳, 女性の肝囊胞からの発癌の典型 的な症例を報告している.この症例は囊胞を穿刺し 3100 cc の貯留液を吸引し, 一時退院したが, 再度症状が出 現し，手術に至った症例である。しかし，このような 発癌形式は CMS が欠如した㐮胞からの腺癌で, 正常の 胆管, 単純性嘦胞からの癌化が考えられ ${ }^{8,54)}, \mathrm{CMS}$ を 有する腺腫からの腺癌とは明らかに異なる組織発生病 態である。

4) Type Iの de novo 発癌の腺癌: Kawarada $ら^{5)}$ の 3 例, Yamasaki $~^{50)}$ の 1 例, 岡見 ${ }^{48)}$, Nakajima ${ }^{18}$ らの壤胞壁に良性上皮が確認できなかった 2 例がこの type に相当すると思われる. しかし，この数年間, 調 べた限りでは類似の症例 ${ }^{63)}$ はあるが, 該当する症例は見 当たらない. 確診の得られた症例は少なく，この type をあえて分ける必要性があるかはさらに検討を要する。

5）腫瘍の付随病変：腫瘍の増大につれて,腹部膨満 感，腹痛など他の肝腫瘍と同様な症状が出現する．そ れ以外に腫瘍内出血が見られ, 自験例でも 2 例経験し ている．その 1 例はショックで来院し，そのまま緊急 手術になり, 他の 1 例は TAE で止血した. 立花ら ${ }^{64)} に$ よる同様の出血例, 陳旧性の出血 ${ }^{65)}$ の報告もある. 輁胞 内出血は, 腺癌ばかりではなく, 良性の襄胞内出血例 もあり, 10例をまとめた報告66)もある. その他, 腫瘍の 増大に伴い, 閉塞性黄疸, 二次的な胆管との交通を来 す症例もある。

\section{4. 治療法と治療成績}

単純性肝壤胞を除外できた段階で，悪性が疑われな くとも, 外科的切除が第一選択となる. 腺癌の場合, 浸潤例, リンパ節転移を認めた症例 67.68$)$ もることから, リンパ郭清も含めた治癒切除を施行すべきである．入 院時の検査で, 肝壤胞と診断され，エタノール注入療 法が行われ, 4 年後には内腔は充実性の腫瘤に完全に置

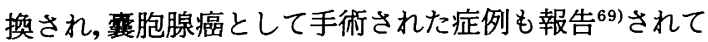
おり，注入療法は襄胞と確診がえられた段階で施行す る. 発見が遅れ, 切除不能の場合は $\mathrm{TAE}^{70)}$, 肝動脈内 化学療法を考慮しても良いであろう. 3-21 年間 follow された腺癌18例のうち，摘出術を受けた衰胞腺癌11例
中, 経過が確認された 9 例では 3 例は再発なく生存, 4 例が再発で死亡， 2 例は病変を有しつつ生存してい る. 男性に限って見ると平均生存率は 3 年であるが, 30代の CMS の女性の患者には死亡例はなかった.CMS のない女性の囊胞腺癌 1 例は術後早期に再発死亡し, 1 例は 21 年間生存中であり, 両者に大きな隔たりが認め られている.本邦においては Kosuge ら ${ }^{71}$ が 4 例の手術 例を報告，2 例は5-53力月 follow し健在であるが，術 中に壤胞が破裂した 1 例と姑息的手術に終わった 1 例 は術後, 26,53力月目に再発で失っている. 尾崎ら ${ }^{72}$ は 切除後 4 年無再発症例を，また岡見らは本邦の腺癌78 例について治癒切除が 66 例 (85\%)で 3 年生存率は $44 \%$ と他の肝腫瘍より良好とは言えないなど，その切除成 績は様々である.岡見らの報告はすべての type の襄胞 性肝癌が含まれており, 治療成績については type 別に 分けて改めて検討する必要があろう。

\section{IV. 病理形態}

\section{1. 肉眼所見}

腺腫, 襄胞腺癌の場合, 多くは多房性で, 腺腫21例 中20例が, 腺腫から癌化したものでは18例中16例が多 房性であったとし ${ }^{16)}, 52$ 例の襄胞腺腫は全例多房性で51 例は macrocystic で，1 例は脺臓に見られる漿液性の microcystic ときわめて類似した形態を示していたとし ている ${ }^{8)}$.一方, 霊胞腺癌18例では17例が多房性で, 同 様に単純性肝㖶胞から癌化したと思われる25例の集計 でも ${ }^{59} 20$ 例が多房性であった。これらの内溶液のほとん どが mucin 様であったが, 単房性の場合は漿液性のも のも見られている.

2. 壤胞壁の構造一とくに Cystadenoma with Mesenchymal Stroma(CMS)について

1985年に Wheeler と Edmondson らは 4 例の癌化症 例を含む17例の症例をもとに CMS という新たな疾患概 念を確立した ${ }^{7)}$.女性に圧倒的に多く見られる腺腫で, 1)㑊胞壁細胞は円柱あるいは立方上皮で，かつ粘液産 生上皮有する，2)紡鍾状の細胞で構成される比較的 厚い間葉系間質を持つという 2 つの特徵的な腫痬構成 所見を呈するものとした.さらに，過去の文献に見ら れた37例を見直すと27例が提唱する CMS の範疇と考え られ，しかも全例女性，平均年齢も 44.1 歳と，彼らの 17例の臨床像と合致する結果がえられた。一方, CMS が認められない 7 症例(男性 5 , 女性 2 )では，平均年 齢53.4歳と CMS とは異なる臨床像で,このような事実 からも両者は全く違うカテゴリーの腫瘍と考えられる と述べている，良性の CMS の外科治療後の生存率は 
1-18年の経過観察で92\%が生存している,一方悪性変 化を来した 4 例の 5 年生存率は $25 \%$ であった.

このCMSは上述した $2 つ の$ 特徽以外に, (1)多房性 (71\%)で, 単房性でも組織学的に macrocystic な部分 がある, (2)貯溜液は粘液性あるいは gelatin 様で希に漿 液性, (3)襄胞壁は $3 \mathrm{~mm}$ 程度の厚さがあり, 外側は線 維性の被膜があるなどの組織構築を有する。この層は 壤胞内に隔壁を形成しており,さらに出血, 炎症, 硝 子化, 石灰化の変化を見ることがあり, この石灰化は $\mathrm{X}$ 線造影で確認でき, 悪性変化を来したものの多くは, 乳頭腺癌で, 良性の CMS にはこのような乳頭状の増殖 像は見られなかったとしている. Gourley ら ${ }^{73)}$ も CMS は希な疾患で, 無症状で増大する, 若い女性に多い病 態で, 1985年に提唱された CMS という新たな疾患概念 に合致し,さらに, 悪性化の potential が高く, 外科的 に切除することが原則で, 本症は1992年まで46例の良 性の CMS と 9 例の悪性化の症例が報告されているとし

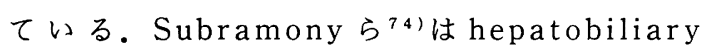
cystadenoma with mesencymal stroma (HCMS) と 命名し, 組織化学, 微細構造を検討している. 4 症例と も女性で 1 例は胆䧶, 3 例は肝の cystadenoma である. MS は多房性で, 疎な紡錘型細胞を有する特徵的な間質 が存在し, 組織化学的検索では, cytokeratin, vimentin, smooth-muscle $\operatorname{actin}^{75)}, \alpha_{1}$-antitrypsin が陽性で, 特 に後者 2 つに対しては強陽性反応が認められたが, chromogranin, CA125, S100蛋白に対しては陰性であっ たとしている.同様に腺腫20例の検索では輁胞壁は cytokeratin, EMA，CEA はすべて陽性, 部分的に chromogranin 陽性細胞は 6 例, 女性患者すべてに“ovarianlike” stroma が認められ，腸上皮化は 6 例中 4 例に見 られ，間質細胞は cytokeratin, EMA, CEA, chromograninすべて陰性, vimentin は20例全例陽性であっ た ${ }^{8)}$.このことより紡錐細胞は myofibroblast あるいは 平滑筋細胞系へ分化したもので, “ovarian-like”stroma はこの分化過程が欠如したものと考えられるとしてい る. 胆䧶, 胆管細胞の progenitor である胎生期の細胞 から発生するという考え方が妥当であるが，なぜ，女 性に多いのかは不明であると述べている.

本邦で CMS まで言及した論文は知る限りでは梛野 $ら^{76)}$, 田中ら ${ }^{44)}$ の報告のみである。梛野らの 7 例のうち 1 例は CMS に相当する症例と考えられ，これまでの報 告の中にも, 高橋 ${ }^{77}$, 高島 ${ }^{78)}$, 松下 ${ }^{79}$, 寺島 ${ }^{43)}$, 村上 ${ }^{21}$ らの症例は全例女性で, 比較的幅の広い間質が見られ, CMS あるいは類似の病変と考えられる. Shimada $5^{80)}$
は CMS よりの癌化 1 例, 胆管からの 1 例を報告してい る. 疑診と考えられる 4 症例 $28,81,82)$, 男性症例 ${ }^{83 ~ 85)}$ も報 告されている. 胆管細胞癌 $(\mathrm{CCC})$ あるいは粘液産生性 胆管癌 ${ }^{83)}$, 露状肝内胆管拡張症の癌化 ${ }^{86,87)}$ との鑑別が問 題となるが, cystic lesion が隹胞腺癌では大部分を占 めるが, CCC の場合, solid な部分が大部分を占める. 粘液産生胆管癌は腫瘍周辺に明らかに胆管が存在し, また胆管との交通が認めらる。

\section{3. “ovarian-like" stroma, endocrine 細胞の存在} について

Devaney ら ${ }^{8}$ は51例の腺腫のうち “ovarian-like” stroma が認められたのは 44 例, 腺癌では18例中 6 例に 見られ，すべてが女性であったとしている．腺癌18例 中, 15例が tubopapillary ca. で10例に atypical area が存在し，そのうち 7 例が女性，5例に“ovarian-like” stroma が認められたとしている.卵巣と類似している ことから, 肝内の “ectopic ovary”説も考えられたが, desmin, muscle-specific actin は組織化学的に卵巣と myofibroblast 両者に陽性であることから,未熟な間質 は初期の肝・胆道系細胞から構成されるとし, そして これらの所見は脺の粘液産生腫瘍との類似性の根拠と もなっている.この点については後で述べる. 卵巣の 漿液性襄胞腺癌の肝転移も全く似たような所見を示 す88).しかし，この “ovarian-like” stroma は部分的 に存在するので実際あっても検出できない場合もある. 1997年, Terada ら ${ }^{91}$ は腺腫, 腺癌に内分泌系の細胞 ${ }^{89}$ が存在することを指摘し，これらが peribiliary gland (PBG) からの発生の可能性を示唆した. 直径が $50 \mu \mathrm{m}$ 以下のいわゆる bile ductules は線維構造, 動脈を有し ていない. peribiliary gland ${ }^{90)}$ は腺胞状の構造を有し, この bile ductule に存在している. 内分泌細胞が胆管 系に認められることは比較的希であるが, 正常の PBG 内に分布しており, 正常肝では20例中 5 例に確認され, さらに胆汁䘖滞の細胆管 ${ }^{91)}$, 肝結石症の $80 \%$ に認められ $ろ^{97}$. Terada ら ${ }^{91}$ は chromogranin 陽性の内分泌細胞は 腺腫 $1 / 3, \mathrm{CMS}$ 腺腫 $1 / 2$, 腺癌 $2 / 3$ に認め, しかもい ずれも PBG は隣接していたとしている.

内分泌細胞の存在を初めて示したのは1992年 Gourley $ら^{73)}$ で CMS 2 例のうち 1 例, Devaney らは18腺腫の うち 6 例, 腺癌 10 例中 1 例に見られたとしている. Bhathal ら ${ }^{92)}$ も bile duct adenoma は PBG から発生すると 述べ, PBG と腺腫の関連性を主張している.PBG と組 織学的に密接な関連性があると考えられる腫啅内の内 分泌細胞の存在 ${ }^{93}$ は襄胞腺腫の新たな特徵的な組織所 
表 2 襄胞形成性悪性肝腫瘍

\begin{tabular}{|c|c|}
\hline Group A & $\begin{array}{l}\text { Cystadenocarcinoma } \\
\text { Type I : Cystadenocarcinoma with CMS } \\
\text { Type II : Cystadenocarcinoma without CMS }\end{array}$ \\
\hline Group B & Carcinoma in a simple cyst of the liver \\
\hline Group C & Bile duct carcinoma with intrahepatic bile duct dilatation \\
\hline Group D & Degeneration cyst in malignant liver tumor \\
\hline
\end{tabular}

見と考えられるかもしれない。

\section{4. 膵腫瘍との類似性}

CMS 内に “ovarian-like” stroma，内分泌細胞等の 存在 $^{94)}$ 等, 肝の襄胞腺腫・腺癌と膵の霊胞性腫痬との成 因, 組織形態学的な共通点が少なくない. Marsh ら ${ }^{95)}$ は腺腫, 腺癌 1 例ずつの自験例を通して, 両藏器が発 生学的に同じ原基から派生していることなどから, 肝 のこれらの疾患と膵の襄胞腺腫・腺癌との類性を指摘 している.膵の囊胞腺腫はBecker ら ${ }^{96)}$, Compagno ら ${ }^{97,98)}$ により microcystic (漿液性) と macrocystic(粘液 性)に分類され，後者の粘液性襄胞腺腫は中年の女性に 多く見られ，多房性で粘液を産生する高い円柱上皮よ りなり,臨床的には悪性と考えられ, Becker ら ${ }^{96) も 9: ~}$ 1 で圧倒的に女性に多い疾患と報告している.乳頭状に 悪性変化を来したのが壤胞腺癌で肝のそれと同様に， 多房性で, 粘液を含有し, 癌部以外にも良性病変と鑑 別が困難な benign looking な像も観察される.このよ うに膵の㖶胞性腫瘍と肝のそれとは臨床像, 組織形態 などかなり類似したところがある.中迫ら ${ }^{99)}$, AlboresSaavedra ${ }^{100)}$ も本疾患は女性に多く, 平均発生年齢が $54.6,51.2$ 歳と肝の襄胞腺癌と同じ年代に発生するな ど, その臨床像も類似していることが窥われる。膵の 獎液性腺腫はいわゆる microcystic（serous）で内腔は グリコーゲン顆粒を含む立方ないしは偏平上皮で被わ れている. Devaney らは槳液性の肝㖶胞腺腫, 腺癌 1 例ずつ経験しており，それらは無数の小亯胞で単層の グリコーゲン顆粒が少ない粘液上皮で被われ, MS を欠 いており,さらに細胞分裂像もなく, 細胞異型も認め られなかったとしている.これらの所見は CMS と全く 異なる type の腺腫で, むしろ膵の serous cystadenoma と類似する腺腫と考えられるとしている。これまで良 性と考えられていたが, しかし悪性, 多発例も報告さ れ，粘液性腺腫と同様に外科手術を行う方向づけがな されつつある。郦胞化した通常型膵管癌は肝臟では末 梢胆管に発生した Group B の胆管癌に相当しょう.

V. あらたな分類への試案(表 2)

これまで述べてきたように, CMS は比較的若い女性
に優位に出現する全く独立した疾患であり, 癌化した 囊胞腺癌もある程度, $\mathrm{CMS}$ の病態を反映している.従っ てCMS を有しない襄胞腺癌は癌の性格も前者とは異な り,さらに肝壤胞から発癌した䧶胞性腺癌はさらにか け離れた病態と考えたい.

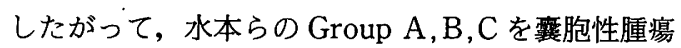
として包含するが, 䧶胞腺癌 (cystadenocarcinoma) は Type I, IIのみを一括して扱い, さらに CMS の有無 で分類し, Type IIIは肝哄胞の癌化としてむしろ, Group 列に別個の病態として扱うべきと考えたい.

\section{まとめ}

肝の襄胞性腺腫, 腺癌は発生頻度が少ないが故に, 肝腫瘍の中でも, その組織発生, 病態が追求把握され づらいところがあった。そんな中で水本, 川原田らの 精力的な取り組みは, 本疾患概念の基礎を作り上げた. しかし，CMS の概念はほほ確立したものと考えられ， さらに “ovarian-like” stroma, 内分泌細胞等の存在 など,これまでの多くの症例を, 再度 CMS という観点 から見直す必要性が出てきた.今後の症例に関しては， 組織化学, 細胞生物学的検索を組み入れた ${ }^{101)}$ 詳細な検 討が必要と考えられる。

本稿を終えるにあたり,ご助言, ご協力いただきました昭 和大学第 1 病理学教室の諸星利男教授, 榎澤哲司先生, 第 2 外科の伊藤洋二, 村上雅彦, 新井浩士の各先生, 高橋信子氏 および旭川医科大学第 2 外科紀野修一先生に心から感謝い たします。

\section{文献}

1）日本肝癌研究会：第13回全国原発性肝癌追跡調查 報告 (1994-1995)

2）村上雅彦, 新井一成, 幡谷 潔, 他: 肝䧶胞腺腫 術後経過中に発症したBiliary Cystadenocarcinomaの 1 例. 日臨外医会誌 $46(10) ： 1336-$ 1343, 1985

3）新井浩士, 村上雅彦, 山崎智已, 他: 異胞内出血 にて緊急手術となった巨大肝襄胞性腺癌の 1 切除 例. Liver Cancer 2(1) : 73-79, 1996 
4）伊藤洋二, 草野満夫, 三田村圭太郎, 他: 価胞内 出血後縦隔腫瘍の発生をみた肝壤胞腺癌の 1 例. Liver Cancer 4(1):65-69, 1998

5) Kawarada Y, Takao H, Mizumoto R: A report 5 cases of cystic bile duct carcinoma of the liver and proposal of a new classification. Jpn Gastroenterol 26(1) : 80-89, 1991

6）川原田嘉文，田岡大樹，水本龍二：“胆管細胞癌 をめぐる諸問題”裹胞性腺癌 一成因と分類一. 肝胆膵 $24(2) ： 261-268,1992$

7) Wheeler DA, Edmondson HA : Cystadenoma With Mesenchymal Stroma (CMS) in the Liver and Bile Ducts. A Clinicopathologic Study of 17 Cases, 4 With Malignant Change. Cancer $56: 1434-1445,1985$

8) Devaney K, Goodman ZD, Ishak KD: Hepatobiliary Cystadenoma and Cystadenocarcinoma. A Light Microscopic and Immunohistochemical Study of 70 Patients. Am J Surg Pathol $18:$ 1078-1091, 1994

9) Terada $T$, Kitamura $Y$, Ohta $T$, et al: Endocrine cells in hepatobiliary cystadenomas and cystadenocarcinomas. Virchows Arch $430: 37-40,1997$

10) Edmondson HA: Tumors of the Liver and Intrahepatic Bile Ducts. Atlas of Tumor Pathology. Section VII-Fascicle 25, 1958

11) Tompson JE, Wolff $M$ : Intrahepatic cystadenoma of bile duct origin with malignant alteration. Report of a case. Treated with total left hepatic lobectomy. Military Medicine $130: 218-224,1965$

12) Willis RA : Carcinoma arising in congenital cysts of the liver. J Pathol \& Bact 55: $492-495,1943$

13）小坂 進, 水上哲次, 橋本之方, 他：撉腫形成型 肝癌について。日外会誌 71(9)：1292-1294, 1970

14）中島 透, 近藤洋一郎: 肝霝胞腺癌の病理. 肝胆 膵 $24(2): 269-274,1992$

15) Buetow PC, Buck JL, Pantongrag-Brown L, et al : Biliary Cystadenoma and Cystadenocarcinoma : Clinical-Imaging-Pathologic Correlations with Emphasis on the Importance of Ovarian Stroma. Radiology 196:805-810, 1995
16）石田秀樹, 中村 達, 鈴木昌八, 他：肝霆胞腺腫 の 1 例. 癌の臨床 $42(5): 567-573,1996$

17) Akwari OE, Seigler HF: Hepatobiliary Cystadenoma with Mesenchymal Stroma. Ann Surg $211: 18-27,1990$

18) Nakajima $T$, Sugano I, Matsuzaki O, et al: Biliary Cystadenocarcinoma of the Liver. A Clinicopathologic and Histochemical Evaluation of Nine Cases. Cancer 69:2426-2432, 1992

19) 大井博道, 中村仁信, 徳永 仰, 他: 肝 Cystadenocarcinoma の画像診断. 日本医学放射線学 会雑誌 $43(9)$ : 1085-1091, 1983

20）長谷川洋, 二村雄次, 早川直和, 他：経皮経肝胆 道鏡検査 (PTCS)により術前診断できたbiliary cystadenocarcinoma の 1 例. 日消外会誌16(7) : 1380-1383, 1983

21）小久保宇, 古井 滋, 大友 邦, 他 : 肝壤胞腺腫・ 腺癌の画像診断. 臨放 30(5)：549-554, 1985

22）小野寺博義, 及川正道, 阿部真秀, 他：超音波集 検で発見された肝嘾胞腺癌の 1 例. Jpn J Med Ultrasonics 13(1) : 64-68, 1986

23）岡住慎一, 竜 崇正, 向井 稔, 他：肝腫瘍の MRI 一胆管細胞癌, 肝膺胞腺癌, 転移性肝癌, 海綿状 血管腫一. 腹部画像診断 $7(5): 443-448,1987$

24) Choi BI, Lim JH, Han MC, et al : Biliary Cystadenoma and Cystadenocarcinoma: CT and Sonographic Findings. Radiology 171: 57-61, 1989

25）猪狩功遺, 有山 襄, 須山正文, 他：䧶胞性腺癌： 臨床像と診断。肝胆膵 $24(2): 275-281,1992$

26）植田 豊, 伊藤義人, 時田和彦, 他：術前に magnetic resonance imaging (MRI) で評価しえた肝袋 胞腺癌の 1 例. 日消誌 91 (1) : 100-104, 1994

27）直居 豊, 富田 貴, 田中卓雄, 他：肝葓胞腺癌 の 1 例. 癌の臨床 $31(10): 1332-1336,1985$

28）村上晃司, 樫本雅彦, 小野彰範, 他：肝哓胞腺癌 の 1 例と本邦報告58例の臨床的検討. 内科 $63(3): 549-554,1989$

29）西 八嗣, 古川正人, 中田俊則, 他: 肝輁胞腺癌 の 1 例. 日消外会誌 $19(7): 1654-1657,1986$

30）小野田尚佳, 西野裕二, 池原照明, 他：CEA, CA19-9, SPan-1 が異常高值を示した肝雚胞腺腫 の 1 例. 肝臓 32(10)：947-954, 1991

31）北尾優子, 関 寿人, 久保田佳嗣, 他：肝襄胞腺 腫の 1 例一穿刺液中腫瘍マーカー測定の有用性に 
ついて一. 日消誌 87(4)：1078-1082，1990

32）竹内丙午, 鈴木正徳, 福原賢治, 他：肝庭胞性疾 患49例の臨床病理学的検討. 日消外会誌 30 (3)： 719-723, 1997

33）岩崎 勇, 岩瀬裕鄉, 長坂宏一, 他：穿刺細胞診 により診断できた肝俩胞腺癌の 1 例. J Jpn Soc Clin Cytol 23(1) : 40-44, 1984

34）松尾 武, 柴田正則, 神原昭吉, 他: 肝襄胞穿刺 細胞診により診断できた肝腺扁平上皮癌と肝襄胞 腺癌の各 1 例. J Jpn Soc Clin Cytol 25(4) : $751-757,1986$

35）香田弘司, 安田 盛, 今峰 徹, 他：エタノール 注入療法が有効であった肝䅹胞状腺癌の 1 剖検例。 肝臓 $67: 741-745,1991$

36) Iemoto $Y$, Kondo $Y$, Nakano $T$, et al: Biliary Cystadenocarcinoma Diagnosed by Liver Biopsy Performed Under Ultrasonographic Guidance. Gastroenterology 84: 399 $-403,1983$

37) Iemoto $Y$, Kondo Y, Fukamachi S : Biliary Cystadenocarcinoma with Peritoneal Carcinomatosis. Cancer 48:1664-1667, 1981

38）稲葉知巳, 系島達也, 小川裕道, 他： $\alpha$-fetoprotein 産生肝襄胞腺癌の 1 例. 肝臓 $32(2): 191-196$, 1991

39) Tomita $T$, Tsuchida $R$, Harada $N$, et al : Cystadenoma and Cystadenocarcinoma of the Liver: Localization of Carcinoembryonic Antigen. Jpn J Surg 16(1) : 62-67， 1986

40）中田雅敏, 落合聖二, 安田是和, 他：肝変胞腺腫 の 1 切除例一病理組織学的 -免疫組織化学的検討 と本邦報告例の集計一. 肝臓 $30(10) ： 1526$ $-1532,1989$

41）岡本友好, 石井雄二, 柳沢 暁, 他：組織学的診 断においても難渋したhepatobiliary cystadenoma の 1 例. Liver Cancer 2(1) : 68-72, 1996

42）辻 信彦，木下博明，広橋一裕，他： 7 年間経過 観察された肝㖶胞腺腫の 1 切除例. 日臨外医会誌 55(11) : 2877-2880, 1994

43）寺島信也, 八子直樹, 櫛田正夫, 他： Biliary cystadenomaの 1 例. 日臨外医会誌 51 (7)：1546 $-1552,1990$

44）田中貞夫, 清水 健,山口淳正, 他：間葉性間質を 伴う肝簬胞腺腫 hepatobiliary cystadenoma with mesenchymal stroma の一外科的切除例. 病 理と臨床 14(12)：1529-1532，1996
45) Woods GL: Biliary Cystadenocarcinoma : Case Report of Hepatic Malignancy Originating in Benign Cystadenocarcinoma. Cancer $47: 2936-2940,1981$

46) Ishak KG, Willis GW, Cummins SD, et al : Biliary Cystadenoma and Cystadenocarcinoma. Report 14 Cases and Review of the Literature. Cancer 39:322-338, 1977

47) More JRS : Cystadenocarcinoma of the Liver. J Clin Path 19:470-474, 1966

48）岡見次郎，左近賢人，藤原義之，他：短期間に進 展し多彩な病変を呈した肝哼胞腺癌の 1 切除例. 日消誌 93(10)：769-774，1996

49）樋口良太，寺本研一，関 俊夫，他：肝襄胞腺癌 が疑われた診断困難な 1 例. Liver Cancer 1(1)： 62-72, 1995

50) Yamasaki I, Tagata K, Hamamoto Y, et al : An Autopsy Case of Mucinous Cystadenocarcinoma of the Liver. Yonago Acta Medica $20: 142-146,1976$

51) Richmond HG : Short articles. carcinoma arising in congental cysts of the liver. J Path Bact $72: 681-683,1956$

52) Bloustein PA : Association of Carcinoma with Congenital Cystic Conditions of the Liver and Bile Ducts. Am J Gastroenterol 67:40-46, 1977

53) Bloustein PA, Silverberg SG : Squamous Cell Carcinoma Originating in an Hepatic cyst. Cancer 38:2002-2005, 1976

54) Azizah N, Paradinas FJ : Cholangiocarcinoma coexisting with developmental liver cysts : a distinct entity different from liver cystadenocarcinoma. Histopathology $4: 391-400,1980$

55）梅枝生成, 林 久博, 小出昭治, 他：肝価胞腺癌 の 1 例. 消化器外科 8(13)：1905-1908, 1985

56）冨岡 勉, 浦 一秀, 山本賢輔, 他: 左肝管内発 育を示した Biliary cystadenocarcinoma の 1 例 一本邦報告例の検討一. 日臨外医会誌 45(5)： $642-647,1984$

57）岩崎 勇, 岩瀬裕郷, 高橋 淳, 他：肝輁胞腺癌 の 1 剖検例. 肝臓 $24(12): 1446-1450,1983$

58）川原田嘉文, 谷川寛自, 東 俊策, 他：肝衰胞内 に発生した乳頭状腺癌の 1 切除例一本邦における 肝䧶胞癌化例と Cystadenocarcinoma の検討一. 日臨外医会誌 $47(12) ： 1644-1650 ， 1986$ 
59）松下一之, 竜 崇正, 佐野友昭, 他: 肝哓胞腺癌 の 2 切除例. 日消外会誌 24(7):2041-2045, 1991

60）李 尚憲, 首藤太一, 池辺 孝, 他: 肝噻胞とし て 10 年間経過観察された肝㩙胞腺癌の 1 切除例. 肝蔵 39(5)：345-348, 1998

61) Cruickshank AH, Sparshott SM : Malignant in natural and experimental hepatic cysts: experiments with aflatoxin in rats and the malignant transformation of cysts in human livers. J Path $104: 185-190,1971$

62) Ameriks J, Appleman H, and Frey c: Malignant Nonparasitic Cyst of the Liver: Case Report. Ann Surg 176 : 713-717, 1972

63）津村裕昭, 布袋裕士, 村上義昭, 他 : 肝 cystadenocarcinoma $の 1$ 例 - cystadenocarcinoma と先天性肝㖶胞の癌化との鑑別について一. 消化 器外科 $12(1): 117-121,1989$

64）立花 進, 田中千凱, 伊藤隆夫, 他: 腫煬内出血 をきたした cystadenocarcinoma of the liver の 1 例. 消化器外科 $14(3): 383-387,1991$

65）小林道也, 荒木京二郎, 小濱祥均, 他: 高度な陳 旧性出血をともなった肝内胆管襄胞腺腫の 1 例. 日消外会誌 $27(10) ： 2248-2252 ， 1994$

66）大平基之, 太田人可, 網塚久人, 他: 肝襄胞内出 血の 2 例. 日消誌 $91(12): 2264-2268,1994$

67）福岡敏幸, 吉川高志, 澤田秀智, 他: リン八゚節転 移を伴った biliary cystadenocarcinoma $の 1$ 切 除例。日消外会誌 19(11)：2288-2291，1986

68）内野純一, 倉内宣明, 佐治 裕, 他: 肝襄胞性腺 癌の治療。肝胆膵 $24(2): 285-293,1992$

69）道鎮明晴, 鈴木潤一, 金井哲伸, 他：エ夕ノール 注入後に壁在結節の出現および増大を認めた肝露 胞性腺癌の 1 例. 日消誌 $93(10): 763-768,1996$

70）島峰良輔, 小田英俊, 中车田浩治, 他: 肝㖶胞腺 癌の 1 剖検例. 肝胆膵 21 (3) : 623-628, 1990

71) Kosuge T, Andersson R, Yamazaki S, et al : Surgical Management of Biliary Cystadenocarcinoma. Hepato-Gastroenterol $39: 417-419$, 1992

72）尾崎喜就, 大野 徹, 山下義信, 他: 肝耣胞腺癌 の1例. 日臨外医会誌 $57(11) ： 2755-2760,1996$

73) Gourley WK, Kumar D, Bouton MS, et al: Cystadenoma and Cystadenocarcinoma with Mesenchymal Stroma of the Liver. Immunohistochemical Analysis. Arch Pathol Lab Med
$116: 1047-1050,1992$

74) Subramony C, Herrera GA, Terbat-Herrera EA : Hepatobiliary Cystadenoma. A Study of Five Cases With Reference to Histogenesis. Arch Pathol Lab Med 117 : 1036-1042, 1993

75) Czernobilsky B, Shezen E, Lifschitz-Mercer $\mathrm{B}$, et al: Alpha smooth muscle actin ( $\alpha-\mathrm{SM}$ actin) in normal human ovaries, in ovarian stromal hyperplasia and in ovarian neoplasms. Virchows Archiv B Cell Pathol 57:55-61, 1989

76）梛野正人, 二村雄二, 早川直和, 他：粘液産生胆 管癌の臨床病理学的研究. 日外会誌 91(6): 695-704, 1990

77）高橋正年, 天目純生, 笠原小五郎, 他: 肝哓胞腺 癌の 1 例. 臨外 35(9): 1329-1334, 1980

78）高島茂樹, 田中良則, 山口明夫, 他: 肝右葉に発 生した巨大な Cystadenocarcinoma の 1 例. 癌の 臨床 26(2)：192-198，1980

79）松下文昭, 横山 仁, 鵜浦雅志, 他: 術後, 肝末 梢部多発生 A-P shunt が消失した肝襄胞腺癌の 1 例. 肝臓 26(8)：1084-1089，1985

80) Shimada M, Kajiyama K, Saitoh A, et al: Cystic Neoplasms of the Liver. Report of two Cases with Special Reference to Cystadenocarcinoma. Hepato-Gastroenterology 43 : $249-254,1996$

81）横井佳博, 中村 達, 鈴木昌八, 他：售胞腺腫よ り癌化したと考えられた肝裹胞腺癌の 1 例. 胆と 膵 $11(12): 1409-1414,1990$

82）石神博昭, 山中義秀, 小川 清, 他: 肝襄胞腺癌 の 1 例. 臨外 $40(7): 835-838,1985$

83）菊池節夫, 八子 亮, 渡辺興治, 他: 閉塞性黄疸 を肝内胆管由来のムチン産生性亯胞腺癌の 1 例. 外科 37(11): 1193-1198, 1974

84）笠井保志, 末永昌宏, 原田明生, 他：肝壤胞腺癌 の 1 治験例. 日消誌 $84(9): 1835-1838,1987$

85）嶋村 剛, 宇根良衛, 中野保明, 他: 術前に襄胞 腺腫との鑑別が困難であった肝䧶胞腺癌の 1 治験 例. 日臨外医会誌 56(3)：594-599，1995

86) Rossi RL, Silverman ML, Braasch JW, et al : Carcinoma Arising in Cystic Conditions. A Clinical and Pathologic Study. Ann Surg 205 : 377-384, 1987

87) Morohoshi $T$, Kunimura $T$, Kanda $M$, et al : Multiple Carcinoma Associated with Anoma- 
lous Arrangement of the Biliary and Pancreatic Duct System. A Report of Two Cases with a Literature Survey. Acta Pathol Jpn 40: 755-763, 1990

88）友尾 靖, 西村治夫, 山田知之, 他：CA-125が再 発後の臨床経過とよく相関した漿液性襄胞腺癌肝 転移の 1 例. 産婦人科の世界 $39: 1105-1108$, 1987

89) O'Hara BJ, McCue PA, Miettinen M : Bile Duct Adenomas With Endocrine Component. Immunohistochemical Study and Comprison With Conventional Bile Duct Adenomas. Am J Surg Pathol 16(1) : 21-25, 1992

90) Haratake J, Tamamoto $O$, Hisaoka $M$, et al: Scanning Electron Microscopic Examination of Microvascular Casts of the Rat Liver and Bile Duct. J UOEH（産業医大誌）12(1)： 19-28, 1990

91) Kurumaya H, Ohta G, Nakamura $Y$ : Endocrine Cells in the Intrahepatic Biliary Tree in Normal Livers and Hepatolithiasis. Arch Pathol Lab Med 113:143-147, 1989

92) Bhathal PS, Hughes NR, Goodman ZD: The so-called bile duct adenoma is a peribiliary gland hamartoma. Am J Surg Pathol 20: 858-864, 1996

93) Bosman FT : Editorial. Endocrine Cells IN Non-Endocrine Tumours. J Path 159 : 181182, 1989

94) Morohoshi T, Held G, Klōppel G : Ezocrine pancreatic tumors and their histological classification. A study based on 167 autopsy and 97 surgical cases. Histopathology $7: 645-661$, 1983

95) Marsh JL, Dahms B, Longmire, Jr WP : Cystadenoma and Cystadenocarcinoma of the Biliary System. Arch Surg 109 : 41-43, 1974

96) Becker WF, Welsh RA, Sratt HS : Cystadenoma and Cystadenocarcinoma of the Pancreas. Ann Surg $161: 845-863,1965$

97) Compagno J, Oertel JE: Microcysteic Adenomas of the Pancreas (Glycogenrich Cystadenomas). A Clinicopathologic Study of 34 Cases. Am J Clin Path 69:289-298, 1978

98) Compagno J, Oertel JE: Mucinous Cystic Neoplasms of the Pancreas with Overt and Latent Malignancy (Cystadenocarcinoma and Cystadenoma). A Clinicopathologic Study of 41 Cases. Am J Clin Path 69:573-580, 1978

99）中迫利明, 吉川達也, 今泉俊秀, 他: 膵哓胞性病 変の臨床病理学的検討, 特に鑑別診断について。 膵臓 $5: 118-120 ， 1990$

100) Albores-Saavedra J, Angeles-Angeles A, Nadji $M$, et al: Mucinous Cystadenocarcinoma of the Pancreas. Morphologic and Immunocytochemical Observations. Am J Surg Pathol 11:11-20, 1987

101）藤原義之, 山田晃正, 大西 直, 他：肝罼胞腺癌 の分子遺伝学的考察. 日消誌 $92 ： 1628,1995$ 